\title{
IL-32 $\gamma$ promotes the healing of murine cutaneous lesions caused by Leishmania braziliensis infection in contrast to Leishmania amazonensis
}

\author{
Rodrigo Saar Gomes ${ }^{1 \dagger}$, Muriel Vilela Teodoro Silva ${ }^{1 \dagger}$, Jéssica Cristina dos Santos ${ }^{1,5+}$, Lucas Luiz de Lima Silva ${ }^{1}$, \\ Aline Carvalho Batista2 ${ }^{2}$ Juliana Reis Machado ${ }^{1}$, Mauro Martins Teixeira ${ }^{3}$, Miriam Leandro Dorta1, \\ Milton Adriano Pelli de Oliveira', Charles A Dinarello ${ }^{4,5}$, Leo A. B. Joosten ${ }^{1,5^{*}}$ and Fátima Ribeiro-Dias ${ }^{1 *}$
}

\begin{abstract}
Background: Interleukin 32 (IL-32) is a pro-inflammatory cytokine induced in patients with American tegumentary leishmaniasis (ATL) caused by Leishmania braziliensis. Here, we investigated whether IL-32 is also expressed in patient lesions caused by L. amazonensis. In addition, we evaluated experimental L. amazonensis and L. braziliensis infections in C57BL/6 transgenic mice for human IL-32y (IL-32үTg) in comparison with wild-type (WT) mice that do not express the IL-32 gene.

Results: Human cutaneous lesions caused by L. amazonensis express higher levels of IL-32 than healthy control skin. In mice, the presence of IL-32y promoted the control of cutaneous lesions caused by L. braziliensis, but not lesions caused by L. amazonensis in an ear dermis infection model. In addition, IL-32YTg mice displayed less tissue parasitism and inflammation in IL-32үTg than WT mice during the healing phase of L. braziliensis infection. Production of antigen-specific pro-inflammatory cytokines was higher in IL-32үTg mice than in WT mice during L. braziliensis infection but not during L. amazonensis infection.

Conclusions: Human cutaneous lesions caused by L. amazonensis express high levels of IL-32. In mice, the presence of IL-32 $\gamma$ contributes to the lesion healing caused by L. braziliensis but not by L. amazonensis. Data suggest that despite the ability for both species to induce IL-32 in humans, the connections between this cytokine and other immune players induced by related species of parasites can lead to distinct outcomes of the murine infections.
\end{abstract}

Keywords: Leishmania amazonensis, Leishmania braziliensis, Cutaneous leishmaniasis, IL-32, Cytokines, Mouse model

\section{Background}

American tegumentary leishmaniasis (ATL) is an infectious disease caused by Leishmania protozoan, affecting the skin, oral or nasal mucosa. Brazil is one of 10 countries that together account for $70-75 \%$ of the cases of tegumentary leishmaniasis in the world [1]. Leishmania amazonensis and Leishmania braziliensis are the main

\footnotetext{
* Correspondence: leo.joosten@radboudumc.nl; fatimardias@gmail.com ${ }^{\dagger}$ Equal contributors

${ }^{1}$ Instituto de Patologia Tropical e Saúde Pública, Universidade Federal de Goiás, Goiânia, Goiás, Brazil

Full list of author information is available at the end of the article
}

species that cause ATL in Brazil. L. amazonensis is associated with the development of localized or diffuse skin lesions whereas $L$. braziliensis is associated with localized cutaneous or mucosal lesions [2-4].

In general, humans or mice infected with L. braziliensis present a stronger cellular immune response against the parasites than human or mice infected with $L$. amazonensis $[5,6]$. L. braziliensis infections cause small cutaneous lesions that regress after a few weeks in C57BL/6 mice. In these mice, it has been demonstrated that the IL-12-IFN- $\gamma / \mathrm{TNF}-\alpha-\mathrm{NO}$ axis controls the parasite infection [7-9]. By contrast, L. amazonensis generates 
chronic and non-healing infection in $\mathrm{C} 57 \mathrm{BL} / 6$ mice with a deficient Th1 cell response $[5,10]$.

IL-32 is a cytokine expressed by several human cells, including NK cells, monocytes/macrophages, T lymphocytes, epithelial cells, endothelial cells, fibroblasts and hepatocytes. IL-32 is predominantly expressed intracellularly and can induce the production of TNF- $\alpha$, IL- 8 and IL-1 $\beta$ [11]. To date, there are nine isoforms of human IL-32 and the highest biological activity has been attributed to IL-32 $\gamma$ [12]. IL-32 is associated with the control or immunopathology of numerous infectious diseases, such as tuberculosis, HIV/AIDS, leprosy and hepatitis [13] likewise in dermatological diseases $[14,15]$.

Although rodents do not naturally produce IL-32, recombinant IL-32 (rIL-32) can activate mouse cells [11]. In addition, injection of rIL-32y into the knee joints of mice leads to arthritis partially mediated by induction of TNF- $\alpha$ [16]. Thus, the use of an experimental animal model to study the role of IL-32 in inflammatory and infectious diseases is made possible by IL-32 humanized transgenic mice.

We previously described that cutaneous and mucosal lesions of patients with ATL caused by L. braziliensis exhibit increased IL-32 expression compared to healthy tissues [17]. Here, we investigated the expression of IL-32 in cutaneous lesions of patients infected with L. amazonensis, and the role of IL-32 $\gamma$ in experimental mouse infections caused by L. amazonensis and L. braziliensis.

\section{Methods}

\section{Patient and control samples}

Patients diagnosed with cutaneous leishmaniasis according to Oliveira et al. [8] and control healthy individuals were submitted to biopsy procedure to obtain fragments from lesions and healthy skin, after signing the consent form.

\section{Immunohistochemical (IHC) analysis for IL-32}

Biopsy fragments were obtained from cutaneous lesions to identify Leishmania species by polymerase chain reaction (PCR) as previously described [8], confirming all samples positive for $L$. amazonensis. Samples of healthy skin $(n=8)$ and a fragment of lesions from patients $(n=5)$ were used for IHC analysis for IL-32 using rabbit polyclonal antibodies to human IL-32 (Abcam Inc., Cambridge, UK), according to Galdino et al. [17]. The tissue expression (epithelium and dermis) of IL-32 was classified as follows: 0 , absence of labelled cells; 1 , $1-25 \%$ of labelled cells; $2,26-50 \%$ of labelled cells; 3 , $51-75 \%$ of labelled cells; and $4,76-100 \%$ of labelled cells). All sections were blindly analyzed using a light microscope (magnification of 400x).

\section{Animals and parasites}

Transgenic mice for human IL-32 were developed by Choi et al. [18] and donated to our group by Dr. Charles Dinarello (University of Colorado, Denver, USA). Six to 8 week old C57BL/6 WT and IL-32 $\gamma \mathrm{Tg}$ mice were used in the experiments. All procedures were followed in accordance with the guidelines and legislation on ethics research.

Leishmania (L.) amazonensis (MHOM/BR/1973/ M2269) and L. (V.) braziliensis (MHOM/BR/2003/IMG) strains were obtained from patients with localized cutaneous lesions $[19,20]$. L. braziliensis strain was obtained and identified by our group, as described by Dorta et al. [19]. Briefly, lesion fragments were macerated in phosphate-buffered saline (PBS) and cultured in Grace's Insect Medium (Gibco, Life Technologies, Carlsbad, USA) supplemented with heat-inactivated $20 \%$ fetal bovine serum (FBS, Sigma-Aldrich, St. Louis, USA) and $100 \mathrm{U} / \mathrm{ml}$ of penicillin/streptomycin (Sigma-Aldrich) at $26{ }^{\circ} \mathrm{C}$. The identification of the species was performed by PCR-RFLP, according to Volpini et al. [21]. Leishmania amazonensis strain was identified and donated to us by Mortara et al. [20].

Leishmania amazonensis and L. braziliensis promastigote forms were cultured in Grace's insect medium supplemented as described above. Parasites of either $L$. amazonensis or L. braziliensis from stationary phase (6th day) of growth were washed three times with sterile PBS, pH 7.4 $\left(1000 \times g, 10 \mathrm{~min}, 10^{\circ} \mathrm{C}\right)$, suspended in PBS and quantified by hemocytometer after fixation with PBS/0.1\% formaldehyde.

Parasite lysates were obtained by 5 freeze-thaw cycles in liquid nitrogen and $37{ }^{\circ} \mathrm{C}$ water bath followed by protein quantification using the Pierce $\mathrm{BCA}$ protein assay (ThermoFisher, Rochester, USA).

\section{Infection, disease progression and histopathological analysis}

Animals were inoculated $\left(1 \times 10^{5}\right.$ promastigotes $/ 10 \mu \mathrm{l}$ of PBS) into the dermis of the left ear. Three independent experiments were performed, with three animals per group in each experiment. Lesion size was measured weekly using a digital caliper. Lesion size is described as the difference between the thickness of the infected ear and the thickness of the uninfected ear [22]. Tissue parasitism was evaluated in the infected ear, draining lymph node (submandibular) and spleen by limiting dilution assay. The results were expressed as the negative logarithm of the parasite titer [23]. Paraformaldehyde fixedear tissue was embedded in paraffin to be processed for histopathological analysis after haematoxylin and eosin $(H \& E)$ staining. The cellular infiltrate evidenced in the inflammatory process was considered [24-26]. 


\section{Cytokine production}

Lesion-draining submandibular lymph node cells from uninfected and infected mice were macerated and maintained in RMPI 1640 medium (Sigma-Aldrich) supplemented with 10\% FBS (Gibco), 1 M HEPES (SigmaAldrich), $2 \mathrm{mM}$ glutamine (Sigma-Aldrich), $100 \mathrm{U} / \mathrm{ml}$ penicillin (Sigma-Aldrich) and $100 \mu \mathrm{g} / \mathrm{ml}$ streptomycin (Sigma-Aldrich). Viable cells were quantified using a hemocytometer by dye exclusion with Trypan blue $0.1 \%$ in PBS. Lymph node cells $\left(5 \times 10^{5}\right.$ cells $\left./ \mathrm{ml}\right)$ were stimulated with antigen from L. amazonensis or L. braziliensis $\left(50 \mu \mathrm{g} / \mathrm{ml}\right.$ ) for $24 \mathrm{~h}$ or $72 \mathrm{~h}$, at $37{ }^{\circ} \mathrm{C}$ and $5 \% \mathrm{CO}_{2}$. TNF$\alpha$ and IL-10 were evaluated in the culture supernatants by commercial enzyme-linked immunosorbent assay (ELISA) kits (R\&D Systems, Minneapolis, USA), according to the manufacturer's protocol. IFN- $\gamma$ was evaluated by ELISA using monoclonal antibodies obtained from hybridoma cultures, according to [27]. All cultures and measurements were done in duplicates.

\section{Statistical analysis}

Data are expressed as means \pm standard deviations or median and individual values and compared using Student's $t$ or Mann-Whitney U tests, respectively. Analyses were performed using Prism software version 6.0 (GraphPad, San Diego, CA, USA). Significance was established as $P<0.05$.

\section{Results}

Expression of IL-32 in lesions of patients with ATL caused by L. amazonensis

We previously demonstrated that IL-32 is highly expressed in cutaneous and mucosal lesions of patients with ATL infected with Leishmania (Viannia) spp., mainly L. braziliensis. In addition, amastigote forms of $L$. braziliensis were able to induce IL-32 $\beta$ in human peripheral blood mononuclear cells [17]. Here, we demonstrate that in cutaneous lesions caused by L. amazonensis infection IL-32 protein expression was also increased when compared to healthy skin specimens $[U=7.5, P=0.0412$ (epithelium) and $U=0.0, P=0.0008$ (inflammatory infiltrate)]. IL-32 was detected both in the epithelium and in the inflammatory infiltrate (Fig. 1a, b).

The role of IL-32 in experimental lesions caused by $L$. amazonensis or L. braziliensis

To understand the precise role of IL-32 in ATL, we infected human IL-32 $\gamma \mathrm{Tg}$ and WT mice with either $L$. amazonensis or L. braziliensis. IL-32 $\gamma \mathrm{Tg}$ mice showed a delayed development of ear lesions caused by $L$. amazonensis (until week 3); however, the size of the lesions were similar to WT mice in later stages of infection (Fig. 2a, c). In contrast, mice infected with $L$. braziliensis demonstrated a significant increase in the lesion size on the 3rd week of infection $\left(t_{(14)}=2.23316, P=0.042\right)$, as well as a reduction of lesion size from week 6 post-infection in IL$32 \gamma \mathrm{Tg}$ mice compared to WT mice (Fig. $2 \mathrm{~b}, \mathrm{c})\left[t_{(14)}=\right.$ 3.29151, $P=0.0053$ (6 weeks); $t_{(14)}=2.16645, P=0.048$ (7 weeks); $t_{14)}=2.82843, P=0.013$ (8 weeks); $t_{(14)}=$ 2.37595, $P=0.032$ (9 weeks)].

We observed that L. amazonensis-infected IL-32 $\gamma \mathrm{Tg}$ mice showed higher lesional parasite load on week 3 of infection compared to WT animals $\left(t_{(14)}=2.52036\right.$, $P=0.024)$. Despite this initial favoring of parasitism in IL-32 $\gamma \mathrm{Tg}$ animals, the growth of $L$. amazonensis in later
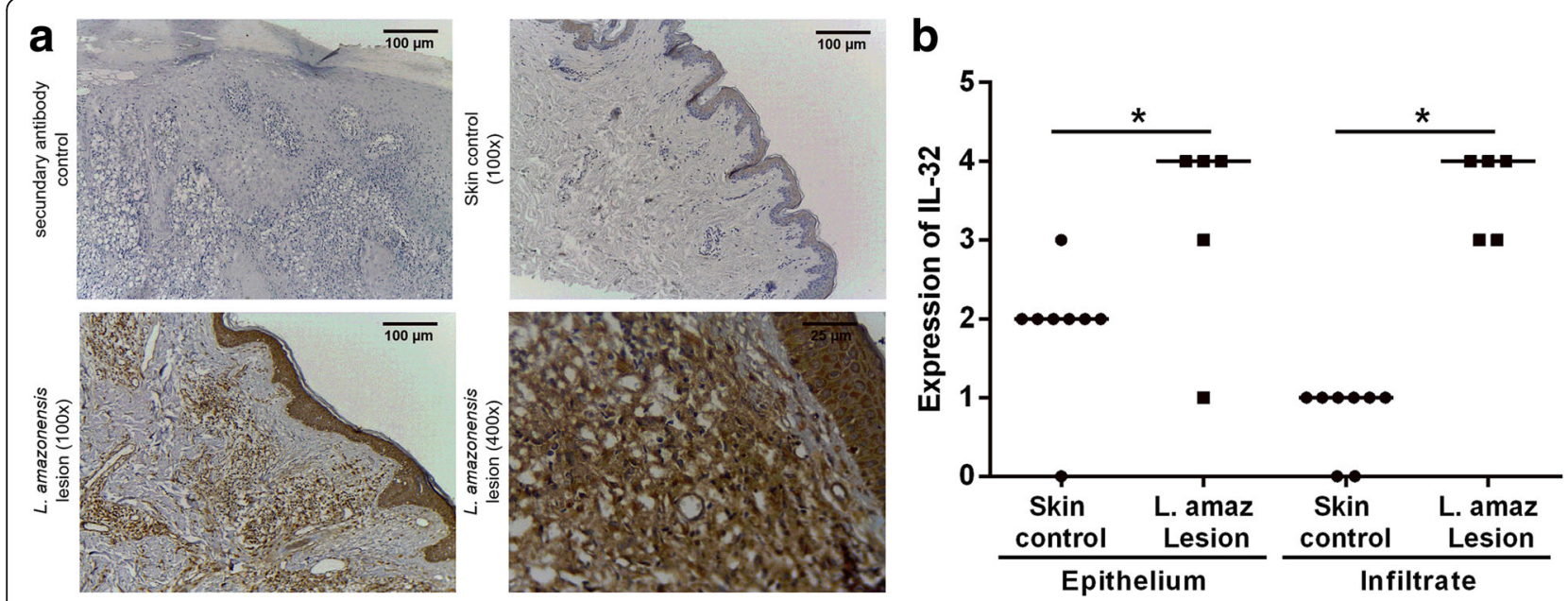

Fig. 1 Expression of IL-32 in American tegumentary leishmaniasis lesions caused by L. amazonensis. a Fragments of lesions from ATL patients infected with L. amazonensis and skin from healthy controls were included in paraffin and submitted to immunohistochemistry for IL-32. The reaction was revealed with 3,3'-Diaminobenzidine and Meyer's hematoxylin used to counterstain. b Evaluation of IL-32 expression score was determined according to the percentage of cells expressing IL-32. The scores represent: 0 (absence of stained cells), 1 (1-25\% of stained cells), 2 (26-50\% stained cells), 3 (51-75\% stained cells), and 4 (76-100\% stained cells). * $P<0.05$ (Mann-Whitney test) 

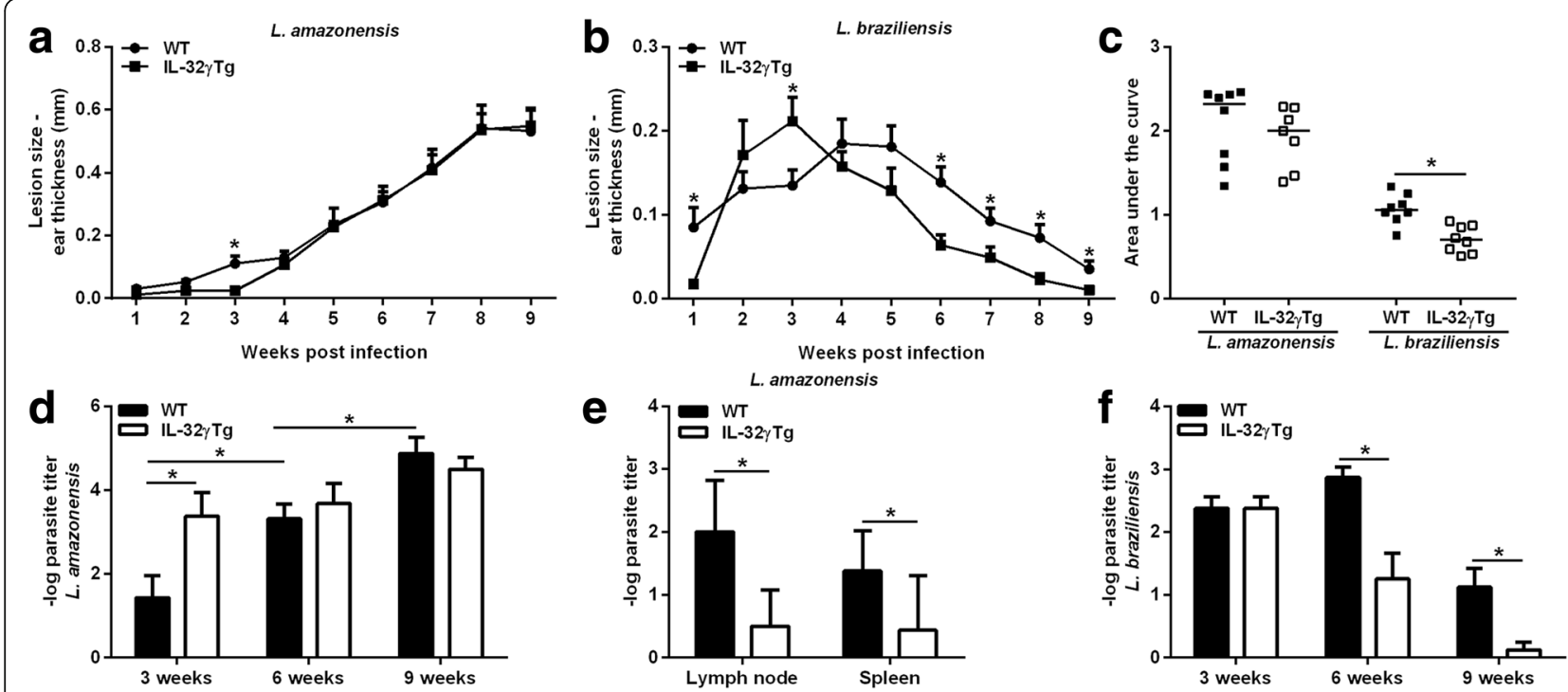

Fig. 2 IL-32 promotes the control of cutaneous infection caused by L. braziliensis, but not caused by L. amazonensis in an ear dermis model. WT and IL-32yTg mice were infected in the left ear with $1 \times 10^{5} \mathrm{~L}$. amazonensis (IFLA/BR/67/PH8) or L. braziliensis (MHOM/BR/2003/IMG) promastigotes in the stationary phase of growth ( 6 days of culture). a Ear thickness was monitored weekly, and lesion size was determined by the difference between infected and uninfected ears. a L. amazonensis infection. b L. braziliensis infection. c Area under the curves is shown for each animal. d Ear parasite numbers were determined on week 3, 6 and 9 post-infection with L. amazonensis using limiting dilution assays. e Lymph node and spleen parasite numbers were determined on week 9 post-infection with L. amazonensis. $\mathbf{f}$ Ear parasite numbers were determined on week 3, 6 and 9 post-infection with $L$. braziliensis using limiting dilution assays. The results presented mean \pm standard deviation (8 animals per group). ${ }^{*} P<0.05(W T \times I L-32 \gamma T g$, Student's t-test)

stages of infection was controlled, whereas parasites grew exponentially in WT mice (Fig. 2d). Although IL-32 $\gamma$ was not able to reduce the $L$. amazonensis infection in the skin, we observed that IL-32 $\gamma$ is important for parasite dis-

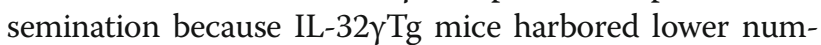
bers of $L$. amazonensis parasites in draining lymph nodes $\left(t_{(6)}=3, P=0.024\right)$ and spleens $\left(t_{(14)}=2.46598, P=0.027\right)$ compared with WT mice in 9 weeks (Fig. 2e). During $L$. braziliensis infection, we observed a strong reduction of parasite burden in IL-32 $\gamma \mathrm{Tg}$ mice $\left[t_{(14)}=3.68751\right.$, $P=0.0024$ (week 6) and $t_{(14)}=3.12076, P=0.0075$ (week 9)] (Fig. 2f). We did not observe L. braziliensis dissemination until the end of the experiments. As expected, WT and IL-32 $\gamma \mathrm{Tg}$ mice exhibited similar histological profiles of lesional inflammatory infiltrates after $L$. amazonensis infection. In contrast, the inflammatory infiltrate was remarkably reduced on weeks 6 and 9 post-infection in $L$. braziliensis-infected IL-32 $\gamma \mathrm{Tg}$ mice compared to WT mice. Despite this, both WT and IL-32 $\gamma$ Tg mice showed a reduction of inflammatory infiltrate at the final stage of infection (9 weeks) when comparing the histopathological aspects on 3 or 6 weeks (Fig. 3).

\section{IL-32 $\gamma$ induces inflammatory cytokines in experimental infections caused by $L$. braziliensis in contrast to $L$. amazonensis}

Lesion-draining submandibular lymph node cells from infected mice were stimulated ex vivo with lysates of $L$. amazonensis or L. braziliensis promastigotes for $24 \mathrm{~h}$, or $72 \mathrm{~h}$ and cytokines were measured in culture supernatants. No difference in the production of IFN- $\gamma$, TNF- $\alpha$ and IL-10 was observed between WT and IL-32 $\gamma \mathrm{Tg}$ animals infected with $L$. amazonensis on weeks 3,6 or 9 post-infection. In contrast, lymph node cells from L. braziliensis-infected IL$32 \gamma \mathrm{Tg}$ animals showed higher cytokine production after antigen-specific stimulation than cells from WT mice (weeks 3 and 6; Fig. 4) $\left[t_{(51)}=3.22153, P=0.0022\right.$ (IFN- $\gamma$, 3 weeks); $t_{(54)}=4.87909, P<0.0001$ (TNF- $\alpha, 6$ weeks); $t_{(14)}=2.92794, P=0.011$ (IL-10, 6 weeks)].

\section{Discussion}

The present study demonstrated that in addition to $L$. braziliensis [17], L. amazonensis induces a strong IL-32 expression in human cutaneous lesions. Furthermore, we showed that human IL-32 $\gamma$ was able to support the healing of skin lesions in L. braziliensis-infected mice, which is in contrast to L. amazonensis caused skin lesions. Based on pro-inflammatory properties of IL-32 $\gamma[11,13]$ we hypothesize that IL-32 $\gamma$ could increase the immune response against L. amazonensis and lead to improved healing of the lesions. Although IL-32 $\gamma$ inhibited the lesional parasite load, IL-32 $\gamma$ did not increase the production of pro-inflammatory cytokines or improved healing. It is well-known that L. amazonensis strongly modulates the host immune response against this parasite [5, 10, 18, 28]. These experimental results, together with the observation 


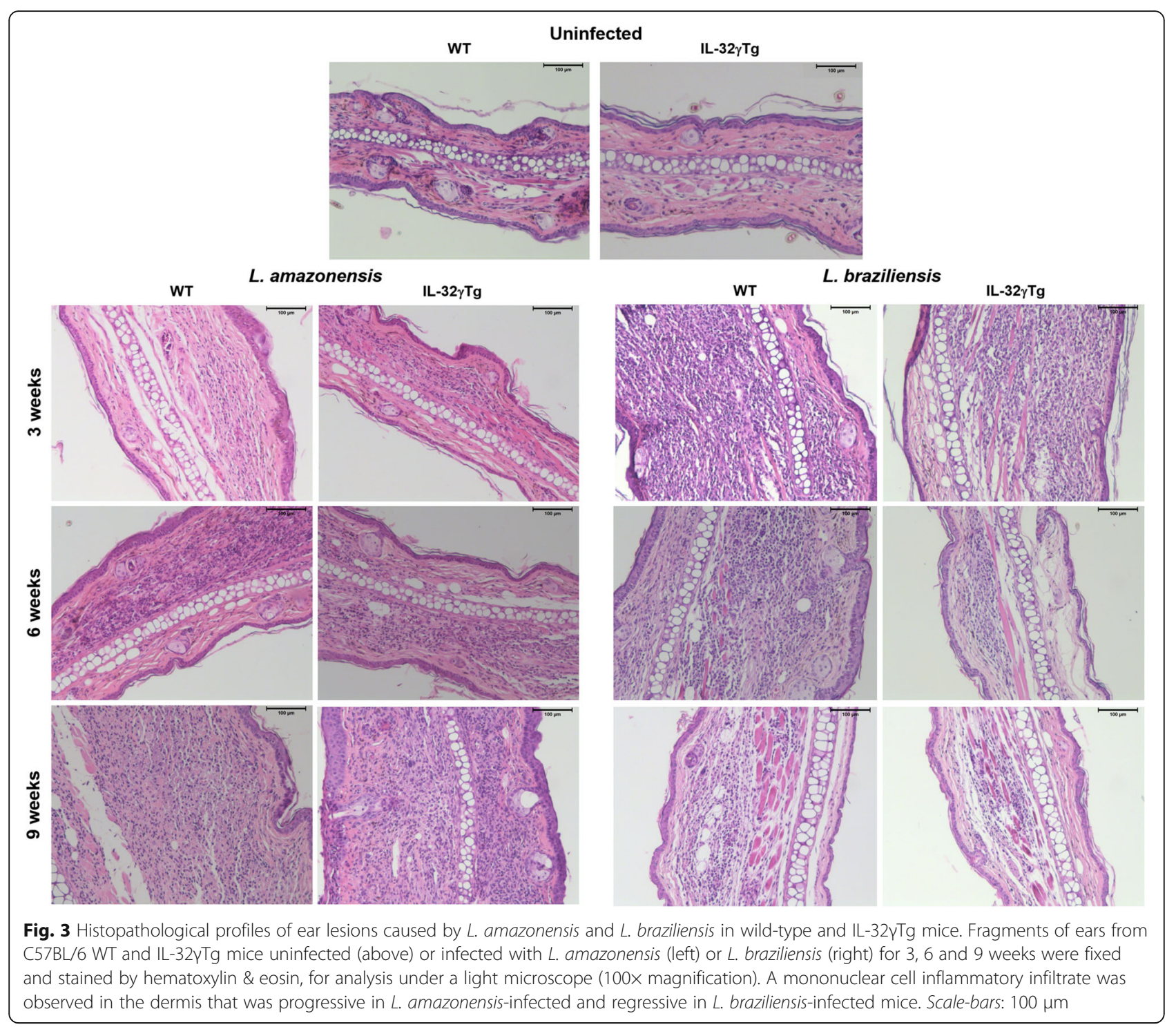

that IL-32 is highly expressed in cutaneous lesions of $L$. amazonensis-infected patients, suggest that even in the presence of IL-32 the parasites and lesion are persistent.

Although it is known that C57BL/6 mice are relatively resistant to L. braziliensis infection [5], we observed that the pro-inflammatory response during L. braziliensis infection was strengthened by IL-32 $\gamma$ without a significant increase of immunopathology. In addition, IL-32 $\gamma$ played an important role in controlling the parasite load, favoring the healing of the skin lesion. Thus, in cutaneous murine lesions caused by L. braziliensis that is restricted to skin and draining lymph node, the pro-inflammatory properties of IL-32 $\gamma$ help the control of the infection. However, in L. amazonensis, which spreads beyond the cutaneous lesions to other tissues and suppress cytokine production, IL-32 $\gamma$ contributes to the control of parasite dissemination but not for skin lesion healing. Differential expression of IL-32y in the tissues during these two infections could explain the results besides intrinsic parasite factors that can interfere with the role of IL-32 $\gamma$. The results underscore the need of unravelling the molecular mechanisms used by $L$. amazonensis parasites to subvert the antileishmanial effect of IL-32 $\gamma$ in skin observed against $L$. braziliensis infection.

It is important to highlight that murine models of leishmaniasis are not a reliable landscape of the immune responses against Leishmania parasites because mice do not produce IL-32. However, murine cells respond to human IL-32 [12]. Some important microbicidal mechanisms are dependent on IL-32, and therefore these latter mechanisms are lost in mice [29]. In this way, this IL$32 \gamma \mathrm{Tg}$ mouse model is very important to reveal novel mechanisms that control or lead to immunopathogenesis in leishmaniasis. 


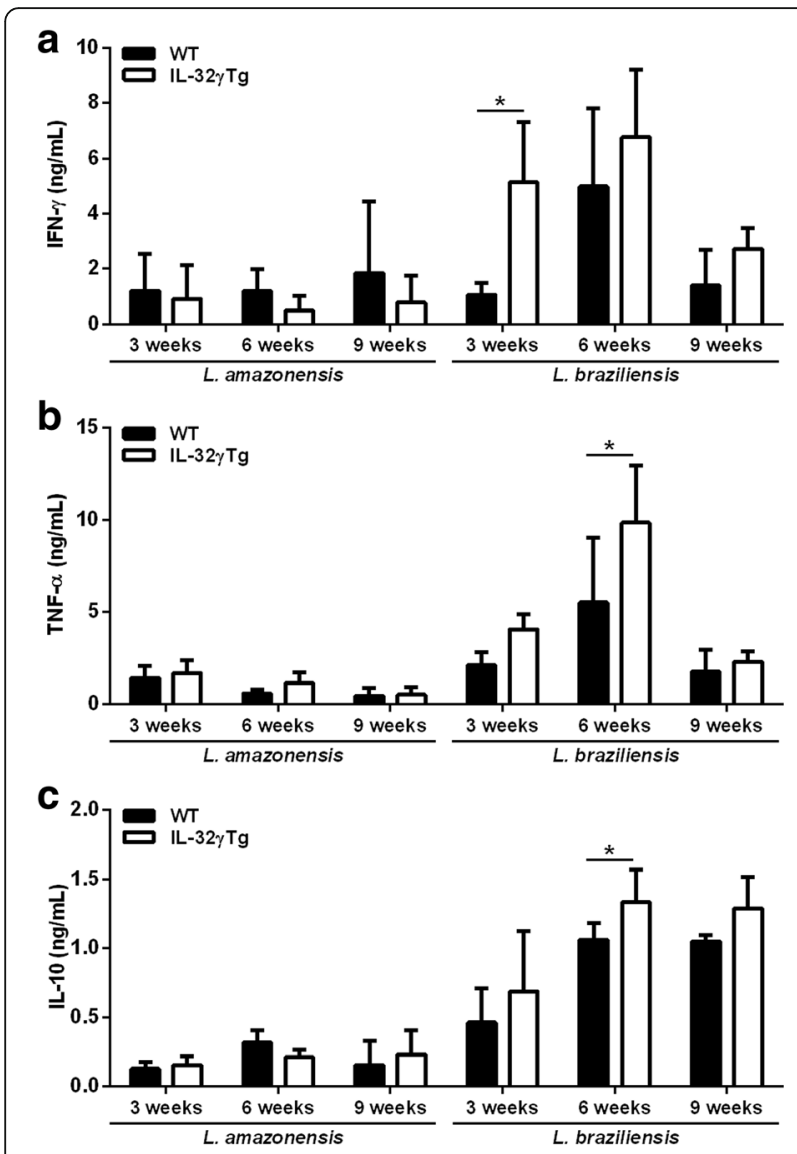

Fig. 4 IL-32 amplifies the production of inflammatory cytokines induced by L. braziliensis during murine ear dermis infection. Lesiondraining submandibular lymph node cells were stimulated with specific antigens from L. amazonensis or L. braziliensis for $24 \mathrm{~h}$ (TNF- $a$ ) or $72 \mathrm{~h}$ (IFN- $\gamma$ and IL-10). The production of (a) IFN- $\gamma$, (b) TNF-a and (c) IL-10 was evaluated by ELISA in culture supernatants. The results represent the mean \pm standard deviation of 8 animals per group. ${ }^{*} P<0.05,(\mathrm{WT} \times \mathrm{IL}-32 \gamma \mathrm{Tg}$, Student's t-test)

\section{Conclusions}

IL-32 $\gamma$ is an important player in the control of L. braziliensis cutaneous infections in contrast to L. amazonensismediated infections, at least in ear dermis infection model. IL-32 $\gamma$ might be a novel target in strategies to control leishmaniasis caused by L. braziliensis.

\section{Abbreviations}

ATL: American tegumentary leishmaniasis; IFN-ץ: Interferon gamma; IL-10: Interleukin-10; IL-12: Interleukin-12; IL-1ß: Interleukin 1 beta; IL-32: Interleukin32; IL-8: Interleukin-8; NK: Natural killer cell; NO: Nitric oxide; Th1: Type 1 T helper cells; TNF-a: Tumor necrosis factor-alpha; WT: Wild-type

\section{Acknowledgments}

We thank Natália Alberto A. Brandão for technical assistance. We also thank Dr. Sam Keating for reviewing the manuscript.

\section{Funding}

This work was supported by CNPq and CAPES, Brazil (project n. 401,887/2013-8 coordinated by Fátima Ribeiro-Dias. Leonardus A.B. Joosten is a PVE fellow of CNPq; FR-D, MAPO, MMT and ACB are fellow researchers of CNPq; JCS is PhD student, fellow of CNPq; RSG is a post-doctoral researcher, fellow of CNPq; MVTS is PhD student, fellow of FAPEG.

Availability of data and materials

All data generated or analyzed during this study are included in this article.

\section{Authors' contributions}

FR-D, LABJ, CAD, RSG and MAPO conceived and designed the study. RSG, MVTS, JCS, LLLS, ACB, MLD, JRM and MMT performed the experiments and analyzed the data. RSG, MVTS, JCS and FR-D wrote the first draft of the manuscript. All authors read and approved the final manuscript.

\section{Ethics approval and consent to participate}

The present study was approved by the research ethics committee of the Hospital das Clínicas/UFG, protocol 44,033,514.0.0000.5078. Healthy donors and patients read and signed the Free and Informed Consent. All animal procedures were followed in accordance with the guidelines and legislation on ethics of the Brazilian Society of Science in Laboratory Animals (SBCAL) and National Council of Control of Animal Experimentation (CONCEA). Project approved by the Institutional Ethics Committee (CEUA/PRPI/UFG, protocol 042/16).

\section{Consent for publication}

Not applicable.

\section{Competing interests}

The authors declare that they have no competing interests.

\section{Publisher's Note}

Springer Nature remains neutral with regard to jurisdictional claims in published maps and institutional affiliations.

\section{Author details}

${ }^{1}$ Instituto de Patologia Tropical e Saúde Pública, Universidade Federal de Goiás, Goiânia, Goiás, Brazil. Faculdade de Odontologia, Universidade Federal de Goiás, Goiânia, Goiás, Brazil. Departamento de Bioquímica e Imunologia, Universidade Federal de Minas Gerais, Belo Horizonte, Minas Gerais, Brazil. ${ }^{4}$ Division of Infectious Diseases, School of Medicine, University of Colorado Denver, Aurora, CO, USA. ${ }^{5}$ Department of Internal Medicine and Radboud Center of Infectious Diseases (RCI), Radboud University Medical Center, Nijmegen, The Netherlands.

Received: 24 February 2017 Accepted: 3 July 2017

Published online: 14 July 2017

\section{References}

1. Alvar J, Velez ID, Bern C, Herrero M, Desjeux P, Cano J, et al. Team WHOLC: Leishmaniasis worldwide and global estimates of its incidence. PLoS One. 2012;7(5):e35671.

2. Reithinger R, Dujardin JC, Louzir H, Pirmez C, Alexander B, Brooker S. Cutaneous leishmaniasis. Lancet Infect Dis. 2007;7(9):581-96.

3. Goto H, Lauletta Lindoso JA. Cutaneous and mucocutaneous leishmaniasis. Infect Dis Clin N Am. 2012;26(2):293-307.

4. Murray HW, Berman JD, Davies CR, Saravia NG. Advances in leishmaniasis. Lancet. 2005;366(9496):1561-77.

5. Maioli TU, Takane E, Arantes RM, Fietto JL, Afonso LC. Immune response induced by New World Leishmania species in C57BL/6 mice. Parasitol Res. 2004:94(3):207-12

6. Silveira FT, Lainson R, De Castro Gomes CM, Laurenti MD, Corbett CE. Immunopathogenic competences of Leishmania (V.) braziliensis and L. (L.) amazonensis in American cutaneous leishmaniasis. Parasite Immunol. 2009;31(8):423-31.

7. Morgado FN, Schubach A, Rosalino CM, Quintella LP, Santos G, Salgueiro M Conceicao-Silva F. Is the in situ inflammatory reaction an important tool to understand the cellular immune response in American tegumentary leishmaniasis? Br J Dermatol. 2008;158(1):50-8.

8. Oliveira MA, Pires Ada S, de Bastos RP, Lima GM, Pinto SA, Pereira LI, et al. Leishmania spp. parasite isolation through inoculation of patient biopsy macerates in interferon gamma knockout mice. Rev Inst Med Trop Sao Paulo. 2010;52(2):83-8. 
9. Diaz NL, Arvelaez FA, Zerpa O, Tapia FJ. Inducible nitric oxide synthase and cytokine pattern in lesions of patients with American cutaneous leishmaniasis. Clin Exp Dermatol. 2006;31(1):114-7.

10. Soong L. Subversion and Utilization of Host Innate Defense by Leishmania amazonensis. Front Immunol. 2012;3:58.

11. Kim SH, Han SY, Azam T, Yoon DY, Dinarello CA. Interleukin-32: a cytokine and inducer of TNFalpha. Immunity. 2005;22(1):131-42.

12. Choi JD, Bae SY, Hong JW, Azam T, Dinarello CA, Her E, et al. Identification of the most active interleukin-32 isoform. Immunology. 2009;126(4):535-42.

13. Ribeiro-Dias F, Saar Gomes R, de Lima Silva LL, Dos Santos JC, Joosten LA. Interleukin 32: a novel player in the control of infectious diseases. J Leukoc Biol. 2016;101(1):39-52

14. Meyer N, Zimmermann M, Burgler S, Bassin C, Woehrl S, Moritz K, et al. IL-32 is expressed by human primary keratinocytes and modulates keratinocyte apoptosis in atopic dermatitis. J Allergy Clin Immunol. 2010;125(4):858-865.e10.

15. Kempuraj D, Conti P, Vasiadi M, Alysandratos KD, Tagen M, Kalogeromitros D, et al. IL-32 is increased along with tryptase in lesional psoriatic skin and is upregulated by substance $P$ in human mast cells. Eur J Dermatol. 2010;20(6):865-7.

16. Joosten LA, Netea MG, Kim SH, Yoon DY, Oppers-Walgreen B, Radstake TR, et al. IL-32, a proinflammatory cytokine in rheumatoid arthritis. Proc Natl Acad Sci USA. 2006;103(9):3298-303.

17. Galdino H Jr, Maldaner AE, Pessoni LL, Soriani FM, Pereira LI, Pinto SA, et al. Interleukin 32gamma (IL-32gamma) is highly expressed in cutaneous and mucosal lesions of American tegumentary leishmaniasis patients: association with tumor necrosis factor (TNF) and IL-10. BMC Infect Dis. 2014;14:249.

18. Choi J, Bae S, Hong J, Ryoo S, Jhun H, Hong K, et al. Paradoxical effects of constitutive human IL-32\{gamma\} in transgenic mice during experimental colitis. Proc Natl Acad Sci USA. 2010;107(49):21082-6.

19. Dorta ML, Oliveira MA, Fleuri AK, Duarte FB, Pinto SA, Pereira LI, Ribeiro-Dias F. Improvements in obtaining New World Leishmania sp. from mucosal lesions: notes on isolating and stocking parasites. Exp Parasitol. 2012;132(2):300-3.

20. Real F, Vidal RO, Carazzolle MF, Mondego JM, Costa GG, Herai RH, et al. The genome sequence of Leishmania (Leishmania) amazonensis: functional annotation and extended analysis of gene models. DNA Res. 2013;20(6):567-81

21. Volpini AC, Passos VM, Oliveira GC, Romanha AJ. PCR-RFLP to identify Leishmania (Viannia) braziliensis and L. (Leishmania) amazonensis causing American cutaneous leishmaniasis. Acta Trop. 2004;90(1):31-7.

22. Lima-Junior DS, Costa DL, Carregaro V, Cunha LD, Silva AL, Mineo TW, et al. Inflammasome-derived IL-1 beta production induces nitric oxide-mediated resistance to Leishmania. Nat Med. 2013;19(7):909-15.

23. de Souza-Neto SM, Carneiro CM, Vieira LQ, Afonso LC. Leishmania braziliensis: partial control of experimental infection by interleukin-12 p40 deficient mice. Mem Inst Oswaldo Cruz. 2004:99(3):289-94.

24. Cangussu SD, Souza CC, Campos CF, Vieira LQ, Afonso LC, Arantes RM. Histopathology of Leishmania major infection: revisiting L. major histopathology in the ear dermis infection model. Mem Inst Oswaldo Cruz. 2009;104(6):918-22.

25. Pereira LI, Dorta ML, Pereira AJ, Bastos RP, Oliveira MA, Pinto SA, et al. Increase of NK cells and proinflammatory monocytes are associated with the clinical improvement of diffuse cutaneous leishmaniasis after immunochemotherapy with BCG/Leishmania antigens. Am J Trop Med Hyg. 2009;81(3):378-83.

26. Gomes CM, Avila LR, Santos JC, Oliveira PG, Tome FD, Pereira LI, et al. Leishmania (Viannia) braziliensis amastigotes from patients with mucosalleishmaniasis have increased ability to disseminate and are controlled by nitric oxide at the early stage of murine infection. Pathog Dis. 2016;74(4): ftw023.

27. dos Santos MS, Vaz Cardoso LP, Nascimento GR, Lino Rde S Jr, Dorta ML, de Oliveira MA, Ribeiro-Dias F. Leishmania major: recruitment of Gr-1+ cells into draining lymph nodes during infection is important for early IL-12 and IFN gamma production. Exp Parasitol. 2008;119(3):403-10.

28. Ji J, Masterson J, Sun J, Soong L. CD4+CD25+ regulatory T cells restrain pathogenic responses during Leishmania amazonensis infection. J Immunol. 2005:174(11):7147-53.

29. Bloom BR, Modlin RL. Mechanisms of defense against intracellular pathogens mediated by human macrophages. Microbiol Spectr. 2016:4(3):MCHD-0006-2015.

\section{Submit your next manuscript to BioMed Central and we will help you at every step:}

- We accept pre-submission inquiries

- Our selector tool helps you to find the most relevant journal

- We provide round the clock customer support

- Convenient online submission

- Thorough peer review

- Inclusion in PubMed and all major indexing services

- Maximum visibility for your research

Submit your manuscript at www.biomedcentral.com/submit

) Biomed Central 